\title{
Pengaruh Efektivitas Penerapan Sistem Informasi Akuntansi, Pemanfaatan Teknologi Informasi dan Motivasi Kerja Pada Kinerja Individu
}

\author{
Ni Luh Gede Dewi Sapitri ${ }^{1}$ \\ I Dewa Nyoman Wiratmaja ${ }^{2}$ \\ ${ }^{1,2}$ Fakultas Ekonomi dan Bisnis Universitas Udayana (Unud), Bali, Indonesia \\ e-mail: sapitridewi234@gmail.com
}

\begin{abstract}
ABSTRAK
Pemanfaatan teknologi informasi dalam instansi pemerintahan dapat membantu karyawan dalam bekerja secara efektif dan efisien. Tujuan dari penelitian ini untuk mengetahui pengaruh efektivitas penerapan sistem informasi akuntansi, pemanfaatan teknologi dan motivasi kerja pada kinerja individu.Metode penelitian yang digunakan pada penelitian ini adalah dengan pedekatan kuantitatif yang berbentuk asosiatif. Penelitian ini dilakukan di Badan Keuangan Daerah (Bakeuda) Kabupaten Tabanan. Penelitian ini menggunakan metode pengambilan sampel dengan purposive sampling yaitu teknik pengambilan sampel dengan pertimbangan atau kriteria tertentu. Jumlah sampel yang digunakan sebanyak 103 responden.Berdasarkan hasil analisis, ditemukan bahwa efektivitas penerapan SIA, pemanfaatan teknologi informasi dan motivasi kerja berpengaruh positif pada kinerja individu di Bakeuda Tabanan.
\end{abstract}

Kata kunci: Efekivitas penerapan sistem informasi akuntansi, pemanfaatan teknologi, motivasi Kerja, kinerja individu.

\begin{abstract}
ABTRACT
The use of information technology in government agencies can help employees work effectively and efficiently. The purpose of this study is to determine the effect of the effectiveness of the application of accounting information systems, technology utilization and work motivation on individual performance. The method of research used in this study is quantitative associative approach. This research was conducted at the Tabanan Regency Regional Finance Agency (Bakeuda). This study uses a sampling method with purposive sampling, namely sampling techniques with certain considerations or criteria. The number of samples used was 103 respondents.Based on the results of the analysis, it was found that the effectiveness of the application of AIS, utilization of information technology and work motivation had a positive effect on individual performance at Bakeuda Tabanan.
\end{abstract}

Keywords: The effectiveness of the application of accounting information system, technology Utilization, motivation work, individual performance.

\section{PENDAHULUAN}

Perkembangan teknologi yang begitu pesat menyebabkan instansi pemerintahan yang bertugas dalam pendapatan dan pengelolaan keuangan daerah dituntut untuk melakukan perubahan di bidang teknologi untuk mendapatkan keunggulan 
kompetitif dan bermanfaat untuk masa yang akan datang dan karyawan dalam instansi pemerintah yang bertugas dalam pendapatan dan mengelola keuangan daerah dituntut untuk memberikan sebuah informasi laporan keuangan yang akurat dan terpecaya. Penggunaan teknologi informasi pada suatu perusahaan dalam menunjang sistem informasi membawa pengaruh terhadap kinerja individu.

Kinerja individu di instansi pemerintahan di Badan Keuangan Daerah Kabupaten Tabanan saat ini sedang mendapatkan sorotan dari masyarakat umum, hal ini dibuktikan oleh adanya protes dari masyarakat terhadap pelayanan pegawai Badan Keuangan Daerah Kabupaten Tabanan yang tidak maksimal. Kasus yang terjadi di Badan Keuangan Daerah Kabupaten Tabanan yaitu pelayanan dari karyawan tidak mendukung tingginya antusiasme masyarakat dalam melakukan administrasi perpajakan yang tinggi. Salah satu keluhan yang disampaikan oleh masyarakat yaitu tidak adanya petugas ketika masyarakat akan melakukan administrasi. Alasan tidak adanya petugas karena odalan (upacara umat hindu) dengan menutup loket pelayanan tanpa adanya pemberitahuan sangat disayangkan oleh masyarakat. Selain penutupan pelayanan tanpa adanya pemberitahuan yang jelas, efektivitas dan efisiensi petugas juga dinilai sangat kurang oleh masyarakat. Sering terlihat banyaknya masayarat yang harus menunggu dari pagi hingga siang untuk mengurus administrasi perpajakan (mediapelangi.com)

Kasus diatas memperlihatkan bahwa kinerja individu di Badan Keuangan Daerah Kabupaten Tabanan kurang optimal dalam memberikan pelayanan sehingga terjadi ketidakpuasan dari masyarakat. Hal ini akan berpengaruh pada 
Pendapatan Asli Daerah yang mengakibatkan defisit anggaran yang mencapai 41 Miliar.

Perusahaan yang memiliki tingkat perkembangan yang baik harus didukung dengan sistem informasi yang berkualitas(Soudani, 2012). Salah satu cara bagi perusahaan untuk meningkatkan kinerja karyawan adalah dengan menyediakan sistem informasi yang memadai dan mendukung tugas dari karyawan(Hafeez-baig \& Gururajan, 2011). Dalam meningkatkan efektivitas dan efisiensi kinerja karyawan, perusahaan perlu menyediakan sistem informasi akuntansi (SIA) (Alsarayreh, Jawabreh, Jaradat, \& ALamro, 2011).

Pemanfaatan TI jika didasarkan oleh pernyataanThompson et al., (1991) dalam Darmini \& Putra, (2007)adalah menggunakan sistem informasi dalam melakukan tugas dengan harapan terdapat manfaat yang berguna bagi pengguna. Jurnali \& Supomo (2002) menyatakan bahwa penelitian tentang sistem informasi pada umumnya befokus pada hubungan antara sistem informasi dan kinerja individu. Selain itu pemanfaatan teknologi informasi juga dapat dihubungkan dengan upaya untuk meningkatkan kinerja. Penggunaan teknologi informasi dapat dijadikan media evaluasi berkaitan dengan dua aspek dalam organisasi yaitu aspek manfaat dan aspek kesesuaian antara teknologi dan tugas.

Teori yang dikembangkan Maslow menyatakan bahwa manusia memiliki lima urutan kebutuhan dasar sebagai individu. Kelima tingkat kebutuhan dan keinginan yang muncul dalam urutan hirarki antara lain:kebutuhan fisiologis, kebutuhan akan rasa aman, kebutuhan social, kebutuhan akan penghargaan dan kebutuhan akan aktualisasi diri. 
Teori ERG yang dikemukakan teori Alderfer, dimana setiap pimpinan agar sukses memotivasi pegawainya harus memenuhi kebutuhan keberadaan (existence $=\mathrm{E})$, kebutuhan berhubungan (relatedness $=\mathrm{R}$ ), kebutuhan untuk berkembang (growth need $=\mathrm{G})$. Kebutuhan berhubugan ini termasuk dalam birokrasi karena pegawai itu adalah mahluk sosial yang selalu membutuhkan kebutuhan sosial dalam bekerja. Kebutuhan berhubungan dengan menggunakan komunikasi antara sesama pegawai dan unit kerja yang ada dan mereka memelihara kebutuhan berhubungan dengan baik.

Efektivitas diartikan sebagai alat ukur tercapainya kesuksesan atau tujuan yang ditetapkan (Wilayanti \& Dharmadiaksa, 2016). Yang dimaksudkan dengan efektivitas yaitu mengenai bagaimana suatu pekerjaan dilakukan dan seberapa jauh cara dalam melakukan pekerjaan tersebut mencapai hasil yang diharapkan(Kristiani, 2012). Apabila hasil pekerjaan itu semakin mendekati sasaran, maka semakin tinggi juga tingkat efektivitasnya.

(Husein, 2008) menyatakan komputer yang merupakan bagian penting dari teknologi informasi sangat membantu kualitas dari informasi yang mengelola informasi secara efektif menjadi sumber daya yang bernilai, pengembangan sistem informasi yang modern akan lebih baik jika menggunakan teknologi informasi. Teknologi adalah pengembangan dan aplikasi dari alat, mesin, material dan proses yang menolong manusia dalam menyelesaikan masalahnya.

Ketika individu menggunakan teknologi informasi yang disediakan dalam melakukan tugas yang diberikan kepada individu tersebut dan kemudian terdapat peningkatan pada kinerjanya, maka individu tersebut telah menerapkan 
pemanfaatan teknologi informasi. Pemanfaatan TI jika didasarkan oleh pernyataanThompson et al., (1991) dalam Darmini \& Putra, (2007)adalah menggunakan sistem informasi dalam melakukan tugas dengan harapan terdapat manfaat yang berguna bagi pengguna.

Motivasi adalah suatu daya pendorong seseorang untuk berprestasi, komitmen terhadap kelompok serta memiliki inisiatif dan optimisme yang tinggi dan motivasi salah satu konsep psikologi yang paling penting dan vital bagi manajer dalam mengarahkan bawahannya untuk mendapatkan tujuan yang baik bagi perusahaan (Ali, Abrar, \& Haider, 2012). Motivasi muncul dari dalam diri manusia karena dengan dorongan oleh adanya unsur suatu tujuan. Tujuan ini menyangkut soal kebutuhan dapat dikatakan bahwa tidak akan ada suatu motivasi apabila tidak dirasakan adanya suatu kebutuhan (Mahardhika, Hamid, \& Ruhana, 2018).

Kinerja dapat diartikan sebagai kualitas serta kuantitas yang dihasilkan sesorang ketika melakukan pekerjaan yang dibebankan kepadanya (Mangkunegara \& Prabu, 2006). (Fahmiswari, 2013)menyatakan kinerja yaitu hasil yang didapat oleh suatu perusahaan selama periode yang telah ditetapkan.(Widodo, 2015), kinerja adalah tingkatan pencapaian hasil atas pelaksanaan tugas tertentu.

Teori TPC atau Technology to Performance Chain yaitu melakukan evaluasi pada pemakai dan kemudian menggunakannya untuk melihat keberhasilan dari teknologi sistem informasi yang digunakan oleh perusahaan. Dengan adanya model tersebut, dapat dilihat secara jelas hubungan dari 
kemampuan pemakai dan tugas pemakai dengan teknologi yang digunakan apakah sudah sesuai atau belum.Ketika pemakai telah memiliki pengetahuan yang cukup serta teknologi informasi yang disediakan perusahaan sesuai dengan kebutuhan pemakai dalam menyelesaikan tugasnya, maka pemakai akan memanfaatkan teknologi informasi tersebut.

(Suratini, Sinarwati, \& Atmadja, 2015), (Antasari, 2015), (Eb, Pretorious, O.J, \& Zuva, 2013), (Utari, 2012) dan (Arsiningsih, Diatmika, \& Darmawan, 2015) menemukan bahwa efektivitas dariSIAmemiliki pengaruh yang positif terhadap kinerja individu. Oleh karena itu, dapat disimpulkan bahwa semakin tepat teknologi yang digunakan oleh karyawan maka semakin mudah melaksanakan tugas yang telah diberikan sehingga semakin bagus teknologi yang digunakan maka semakin meingkatkan kinerja individu.

$\mathrm{H}_{1}$ : Pengaruh efektivitas penerapan sistem informasi akuntansi berpengaruh positif pada kinerja individu.

Teori TPC atau Technology to Performance Chain yaitu melakukan evaluasi pada pemakai dan kemudian menggunakannya untuk melihat keberhasilan dari teknologi sistem informasi yang digunakan oleh perusahaan. Dengan adanya model tersebut, dapat dilihat secara jelas hubungan dari kemampuan pemakai dan tugas pemakai dengan teknologi yang digunakan apakah sudah sesuai atau belum.Ketika pemakai telah memiliki pengetahuan yang cukup serta teknologi informasi yang disediakan perusahaan sesuai dengan kebutuhan pemakai dalam menyelesaikan tugasnya, maka pemakai akan memanfaatkan teknologi informasi tersebut. 
Pemanfaatan merupakan perilaku dari menggunakan teknologi dalam melakukan pekerjaan (Thompson et al., 1991). Teknologi informasi yaitu komputer sangat membantu kinerja dalam organisasi/perusahaan. Jumlah komputer dalam organisasi/perusahaan sangat mempengaruhi dalam implementasi teknologi informasi.

(Utari, 2012)menemukan adanya pengaruh positif dari TI pada kinerja dari individu. Memperkuat temuan dari penelitian (Utari, 2012),(Wahyuni, 2014) dan (Astuti \& Dharmadiaksa, 2014)juga menemukan hubungan yang serupa. Oleh karena itu, dapat disimpulkan kemajuan teknologi yang memanfaatkan sistem informasi berbasis komputer dalam pekerjaan sehari-hari akan dapat mendorong para individu untuk bekerja serta memberikan layanan kepada customers secara optimal dan teknologi informasi dapat dimanfaatkan secara efektif untuk memberikan kontribusi terhadap kinerja.

$\mathrm{H}_{2}$ : Pemanfaatan teknologi informasi berpengaruh positif pada kinerja individu

Teori ERG yang didasarkan pada kebutuhan manusia akan keberadaan (exsistence), hubungan (relatedness), dan pertumbuhan (growth). Pada teori ini, pemimpin akan sukses memotivasi karyawannya apabila memenuhi kebutuhan akan hidupnya. Motivasi kerja adalah ketika individu terdorong untuk menyelesaikan suatu pekerjaan dengan menjalankan indikator pekerjaan yang ada dengan harapan mendapatkan hasil pekerjaan yang baik. Motivasi merupakan hal penting yang perlu dimiliki oleh pegawai(Runtuwene, 2015). Menurut teori hirarki kebutuhan Maslow, seorang individu akan termotivasi bekerja apabila suatu perusahaan/organisasi dapat memenuhi kebutuhan hidupnya, dalam teori 
hirarki dijelaskan terdapat lima kebutuhan manusia yang terpenuhi yaitu kebutuhan fisiologis, rasa aman, sosial, penghargaan dan akualisasi diri. Lima kebutuhan tersebut akan mendorong seorang individu dalam bekerja.

Terdapat dua faktor yang memiliki pengaruh terhadap kinerja yaitu faktor kemampuan serta faktor motivasi (Mangkunegara \& Prabu, 2006). Masih sejalan dengan pernyataan sebelumnya,menurut Mathis \& Jackson (2006) kemampuan, motivasi, dan dukungan individu yang diterima merupakan hal penting yang dilihat oleh perusahaan dari diri seseorang. Penelitian (Cahyono, 2005) menguji hubungan motivasi dengan kinerja karyawan, bahwa motivasi kerja berpengaruh positif terhadap kinerja karyawan. Oleh karena itu, dapat disimpulkan bahwa kinerja individu dapat meningkat apabila mendapat dorongan dalam diri sendiri maupun dari orang lain serta didukung dari diberikanya tunjangan-tunjangan yang memenuhi kebutuhan karyawan. Dengan adanya motivasi kerja maka kinerja individu akan meningkat.

$\mathrm{H}_{3}$ : Motivasi Kerja berpengaruh positif pada kinerja individu.

\section{METODE PENELITIAN}

Pendekatan yang digunakan dalam penelitian ini adalah pendekatan kuantitatif berbentuk asosiatif. Menurut (Sugiyono, 2017) penelitian asosiatif merupakan penelitian yang bertujuan untuk mengetahui hubungan antara dua variabel atau lebih. Penelitian ini membahas pengaruh efektivitas penerapan sistem informasi akuntansi, pemanfaatan teknologi informasi dan motivasi kerja pada kinerja individu. Penelitian ini dilakukan di Badan Keuangan Daerah (Bakeuda) 
Kabupaten Tabanan, yang terletak di Jln. Pahlawan No. 19, Delod Peken, Kecamatan Tabanan.Objek penelitian adalah suatu atribut atau nilai orang, obyek atau kegiatan yang mempunyai variasi tertentu yang diterapkan oleh peneliti untuk dipelajari dan kemudian memperoleh kesimpulan (Sugiyono, 2017). Dalam penelitian ini, lingkup objek penelitian yang diterapkan penulis sesuai dengan permasalahan yang akan diteliti adalah kinerja individu di Badan Keuangan Daerah Kabupaten Tabanan.

Variabel adalah segala sesuatu yang berbentuk apa saja yang ditetapkan oleh peneliti untuk dipelajari sehingga diproleh informasi tentang hal tersebut, kemudian ditarik kesimpulan (Sugiyono, 2017). Dalam penelitian ini terdapat dua jenis variabel yaitu variabel terikat.

Variabel terikat (Dependent Variable) adalah suatu variabel yang dipengaruhi atau menjadi akibat karena adanya vaeiabel bebas atau variabel independen (Sugiyono, 2017). Variabel dependen dalam penelitian ini adalah kinerja individu.

Variabel bebas (Independent Variable) adalah suatu variabel yang mempengaruhi atau menjadi sebab perubahan atau timbulnya variabel terikat atau variabel deenden (Sugiyono, 2017). Variabel independen dalam penelitian ini adalah efektivitas sistem informasi akuntansi, pemanfaatan teknologi informasi dan motivasi kerja.

Menurut (Sajady, Dastgir, \& Hashem Nejad, 2008), suatu sistem dikategorikan sebagai sistem yang efektif dilihat dari apakah informasi yang dihasilkan dapat dijadikan dasar sebagi pembuat keputusan, kualitas dari informasi akuntansi yang 
dihasilkan oleh sistem, evaluasi kerja, pengendalian internal yang memfasilitasi transaksi perusahaan. Adapun indikator pengukuran variabel efektivitas penerapan sistem informasi akuntansi yang digunakan dalam penelitian ini diadopsi dari penelitian (Astuti \& Dharmadiaksa, 2014) yaitu keamanan data, waktu, ketelitian, relevansi dan variasi laporan.

Pemanfaatan TI jika didasarkan oleh pernyataanThompson et al., (1991) dalam Darmini \& Putra, (2007)adalah menggunakan sistem informasi dalam melakukan tugas dengan harapan terdapat manfaat yang berguna bagi pengguna. Untuk melihat seberapa jauh TI dimanfaatkan dapat dilihat dari seberapa banyak software yang bisa dikuasai oleh pengguna, persepsi atau manfaat dari software bagi penggunaserta seberapa sering pengguna menggunakan atau memanfaatkansoftware tersebut (Kasandra \& Juliarsa, 2016). Adapun indikator pengukuran variabel pemanfaatan teknologi informasi yang digunakan dalam penelitian ini diadopsi dari penelitian (Kasandra \& Juliarsa, 2016) yaitu sosial, affect, kompleksitas, kesesuaian tugas, konsekuensi jangka panjang dan kondisi yang memfasilitasi.

Motivasi kerja merupakan suatu proses pemberian dorongan kepada seseorang untuk dapat bekerja sesuai dengan batasan yang diberikan demi mencapai tujuan organisasi secara maksimal (Dewi \& Puspita., 2014). Indikator pengukuran variabel motivasi kerja dalam penelitian ini diadopsi dari instrumen yang dikembangkan oleh (Simanjuntak, 2012) dan (Dewi \& Puspita., 2014) yang telah dimodifikasi, yaitu (1) rasa aman dan nyaman dalam bekerja, (2) tanggung 
jawab, (3) kelengkapan peralatan kerja, (4) semangat kerja dan (5) inisiatif dan kreatif .

Kinerja dapat diartikan sebagai kualitas serta kuantitas yang dihasilkan sesorang ketika melakukan pekerjaan yang dibebankan kepadanya (Mangkunegara \& Prabu, 2006). (Fahmiswari, 2013)menyatakan kinerja yaitu hasil yang didapat oleh suatu perusahaan selama periode yang telah ditetapkan.(Widodo, 2015), kinerja adalah tingkatan pencapaian hasil atas pelaksanaan tugas tertentu. Indikator pengukuran variabel kinerja individu yang digunakan dalam penelitian ini diadopsi dari penelitian (Astuti \& Dharmadiaksa, 2014) yaitu produktivitas, efektivitas, kuantitas kerja, kualitas kerja, dan pelayanan sistem komputer.

Data kuantitatif dalam penelitian ini adalah hasil jawaban karyawan pada Bakeuda Tabanan dan data skor nilai dari jumlah kuesioner yang telah diisi oleh responden. Data primer dalam penelitian ini adalah jawaban responden terhadap pertanyaan dalam kuesioner.Pernyataan yang disajikan dalam kuesioner akan diukur menggunakan skala likert.

Populasi dalam penelitian ini adalah seluruh ASN (Aparatur Sipil Negara) dan Pegawai Kontrak yang sudah bekerja lebih dari 1 (satu) tahun di Bakeuda Tabanan, yaitu sebanyak 243 orang dengan rincian sebagai berikut: 
Tabel 1.

Penentuan Populasi

\begin{tabular}{lccc}
\hline \multicolumn{1}{c}{ Bidang } & ASN & Kontrak & Total \\
\hline $\begin{array}{l}\text { Sekretariat } \\
\text { Bidang PBB-P2 (Pajak Bumi dan Bangunan }\end{array}$ & 36 & 32 & 68 \\
$\quad \begin{array}{l}\text { Perdesaan dan Perkotaan) dan BPHTB } \\
\quad \text { Bea Perolehan Hak atas Tanah dan }\end{array}$ & & & \\
$\quad$ Bangunan) & 22 & 8 & 30 \\
$\begin{array}{l}\text { Bidang Pajak Daerah lainnya, Dana trsansfer } \\
\quad \text { dan penerimaan lain-lain }\end{array}$ & 18 & 13 & 31 \\
Bidang Anggaran & 9 & 7 & 16 \\
Bidang Perbendaharaan & 35 & 6 & 41 \\
Bidang Aset & 20 & 12 & 32 \\
Bidang Akuntansi dan Pelaporan & 16 & 9 & 25 \\
Total & & & 243 \\
\hline
\end{tabular}

Sumber: Badan Keuangan Daerah Kabupaten Tabanan, 2019

Metode penentuan sampel yang digunakan dalam penelitian ini adalah purposive sampling. Sampel dalam penelitian ini adalah seluruh Aparatur Sipil Negara dan Pegawai Kontrak yang menggunakan sistem informasi akuntansi dan memiliki masa kerja minimal satu tahun yaitu sebanyak 103 orang.

Tabel 2.

Penentuan Sampel

\begin{tabular}{lc}
\hline \multicolumn{1}{c}{ Keterangan } & Jumlah \\
& Karyawan \\
\hline Populasi Jumlah Karyawan & 243 \\
Bukan Pengguna sistem informasi akuntansi & $(130)$ \\
Pengguna sistem informasi akuntansi & 113 \\
Masa Kerja < 1 Tahun & $(10)$ \\
Jumlah Sampel & 103 \\
\hline Sumber: Badan Keuangan Daerah Kabupaten Tabanan, 2019
\end{tabular}

Sampel penelitian yang berjumlah 103 orang tersebut, tersebar di bidangbidang yang ada di Bakeuda Tabanan. 
ISSN: 2302-8556

E-Jurnal Akuntansi

Vol.28.2.Agustus (2019): 1263-1294

Tabel 3.

Sampel

\begin{tabular}{lc}
\hline \multicolumn{1}{c}{ Bidang } & Jumlah \\
\hline Sekretariat & 25 \\
Bidang PBB-P2 (Pajak Bumi dan Bangunan Perdesaan Dan Perkotaan) & \\
dan BPHTB (Bea Perolehan Hak atas Tanah dan Bangunan) & - \\
& \\
Bidang Pajak Daerah lainnya, Dana Transfer dan penerimaan lain-lain & 1 \\
Bidang Anggaran & 16 \\
Bidang Perbendaharaan & 36 \\
Bidang Aset & - \\
Bidang Akuntansi dan Pelaporan & 25 \\
Total & 103 \\
\hline Sumber: Badan Keuangan Daerah Kabupaten Tabanan 2019
\end{tabular}

Sumber: Badan Keuangan Daerah Kabupaten Tabanan, 2019

Teknik pengumpuan data dalam penelitian ini adalah wawancara dan kuesioner .

\section{HASIL DAN PEMBAHASAN}

Data dikumpulkan dengan menyebarkan kuesioner ke lima bidang di Badan Keuangan Daerah Kabupaten Tabanan. Berdasarka Tabel 4 dapat dilihat jumlah kuesioner yang disebar pada penelitian ini sebanyak 103 kuesioner. Ringkasan penyebaran dan pengambilan kuesioner dapat dilihat pada Tabel 4.

Tabel 4.

Data Pengambilan dan Pengembalian Kuesioner

\begin{tabular}{lc}
\hline \multicolumn{1}{c}{ Keterangan } & Jumlah \\
\hline Kuesioner yang tersebar & 103 \\
Kuesioner yang tidak kembali & 22 \\
Kuesioner yang dikembalikan & 81 \\
Kuesioner yang digunakan & 81 \\
Tingkat pengembalian/ Response Rate & \\
81/103 x 100 & $79 \%$ \\
Useable Response Rate & $79 \%$ \\
\hline S1/103 x 100 &
\end{tabular}

Karakteristik responden akan menyajikan profil dari 81 responden yang berpartisipasi dalam pengisian kuesioner. Data mengenai profil responden tersebut dapat di lihat pada Tabel 5. 
Tabel 5.

Krakteristik Responden

\begin{tabular}{clcc}
\hline \multicolumn{1}{c}{ Keterangan } & Jumlah (Orang) & Persentase (\%) \\
\hline \multirow{2}{*}{1} & Jenis Kelamin & & \\
& Laki-Laki & 35 & $43.2 \%$ \\
& Perempuan & 46 & $56.8 \%$ \\
& Total & 81 & $100.0 \%$ \\
2 Pendidikan Terakhir & & \\
Sma/Smk & 9 & $11.1 \%$ \\
Diploma & 8 & $9.9 \%$ \\
S1 & 60 & $74.1 \%$ \\
S2 & 4 & $4.9 \%$ \\
& S3 & 0 & $0.0 \%$ \\
& Total & 81 & $100.0 \%$ \\
Lama Bekerja & & \\
& $<5$ Tahun & 12 & $14.8 \%$ \\
5-10 Tahun & 27 & $33.3 \%$ \\
11-15 Tahun & 24 & $29.6 \%$ \\
16-20 Tahun & 8 & $9.9 \%$ \\
> 20 Tahun & 10 & $12.3 \%$ \\
Total & 81 & $100.0 \%$ \\
\hline
\end{tabular}

Sumber:Data diolah, 2019

Penjelasan mengenai data karakteristik responden pada Tabel 5 dapat dijelaskan sebagai berikut:

Informasi mengenai jenis kelamin menunjukan proporsi responden lakilaki dan perempuan. Jumlah resonden laki-laki yaitu sebanyak 35 orang (43.2\%) dan jumlah responden perempuan sebanyak 46 orang $(56.8 \%)$.

Informasi mengenai pendidikan digunakan untuk mengetahui jenjang pendidikan yang dimiliki responden. Responden yang memiliki tingkat pendidikan SMA/SMK sebanyak 9 orang (11.1\%). Diploma sebanyak 8 orang (9.9\%), S1 sebanyak 60 orang (74.1\%) dan S2 sebanyak 4 orang (4.9\%).

Informasi mengenai lama bekerja digunakan untuk mengenai lama responden bekerja di Badan Keuangan Daerah Kabupaten Tabanan. Responden 
dengan lama bekerja $<5$ tahun sebanyak 12 orang (14.8\%), 5-10 tahun sebanyak 27 orang (33.3\%), 11-15 tahun sebanyak 24 orang (29.6\%), 16-20 tahun sebanyak 8 orang $(9.9 \%)$, dan $>20$ tahun sebanyak 10 orang $(12.3 \%)$.

Hasil uji validitas pada penelitian ini menyatakan bahwa seluruh indikator pernyataan dalam kuesioner dengan variabel kinerja individu (Y), efektivitas penerapan sistem informasi akuntansi $\left(\mathrm{X}_{1}\right)$, pemanfaatan teknologi informasi $\left(\mathrm{X}_{2}\right)$ dan motivasi kerja $\left(\mathrm{X}_{3}\right)$ memiliki pearson correlation yang lebih besar dari 0,30 sehingga indikator tersebut memenuhi syarat valititas data, sesuai dengan Tabel 6.

Tabel 6.

Hasil Uji Validitas

\begin{tabular}{ccccc}
\hline No & Variabel & Kode Instrumen & $\begin{array}{c}\text { Nilai Pearson } \\
\text { Correlation }\end{array}$ & Keterangan \\
\hline 1 & Efektivitas Penerapan & $\mathrm{X}_{1.1}$ & 0,821 & Valid \\
& Sistem Informasi Akuntansi & $\mathrm{X}_{1.2}$ & 0,811 & Valid \\
& (X1) & $\mathrm{X}_{1.3}$ & 0,798 & Valid \\
& & $\mathrm{X}_{1.4}$ & 0,784 & Valid \\
& & $\mathrm{X}_{1.5}$ & 0,824 & Valid \\
2 & Pemanfaatan Teknologi & $\mathrm{X}_{2.1}$ & 0,849 & Valid \\
& Informasi (X2) & $\mathrm{X}_{2.2}$ & 0,830 & Valid \\
& & $\mathrm{X}_{2.3}$ & 0,836 & Valid \\
& & $\mathrm{X}_{2.4}$ & 0,825 & Valid \\
& & $\mathrm{X}_{2.5}$ & 0,848 & Valid \\
& & $\mathrm{X}_{2.6}$ & 0,828 & Valid \\
3 & Motivasi Kerja (X3) & $\mathrm{X}_{3.1}$ & 0,791 & Valid \\
& & $\mathrm{X}_{3.2}$ & 0,695 & Valid \\
& & $\mathrm{X}_{3.3}$ & 0,831 & Valid \\
& & $\mathrm{X}_{3.4}$ & 0,777 & Valid \\
& & $\mathrm{X}_{3.5}$ & 0,821 & Valid \\
& & $\mathrm{Y}_{1}$ & 0,835 & Valid \\
& Kinerja Individu (Y) & $\mathrm{Y}_{2}$ & 0,807 & Valid \\
& & $\mathrm{Y}_{3}$ & 0,787 & Valid \\
& & $\mathrm{Y}_{4}$ & 0,852 & Valid \\
& & $\mathrm{Y}_{5}$ & 0,890 & Valid \\
& & & &
\end{tabular}

Sumber: Data diolah, 2019

Hasil pengujian data menunjukkan bahwa nilai Cronbach's alpha lebih besar dari 0,70. Hal ini menunjukkan bahwa data penelitian dinyatakan reliable. Tabel 7 menyajikan hasil uji reliabilitas instrumen penelitian. 
Tabel 7.

Hasil Uji Reliabilitas

\begin{tabular}{clcc}
\hline No & Variabel & Cronbach's Alpha & Keterangan \\
\hline 1 & $\begin{array}{l}\text { Efektivitas Penerapan Sistem } \\
\text { Informasi Akuntansi (X1) }\end{array}$ & 0,867 & Reliabel \\
2 & $\begin{array}{l}\text { Pemanfaatan Teknologi Informasi } \\
(\mathrm{X} 2)\end{array}$ & 0,913 & Reliabel \\
3 & Motivasi Kerja (X3) & 0,842 & Reliabel \\
4 & Kinerja Individu (Y) & 0,891 & Reliabel \\
\hline
\end{tabular}

Sumber:Data diolah, 2019

Hasil pengujian data menunjukkan bahwa nilai Cronbach's alpha lebih besar dari 0,70. Hal ini menunjukkan bahwa data penelitian dinyatakan reliable.

Tabel 8.

Hasil Uji Deskriptif

\begin{tabular}{clccccc}
\hline No & \multicolumn{1}{c}{ Variabel } & $\begin{array}{c}\text { Jumlah } \\
\text { Pernyataan }\end{array}$ & Min. & Maks. & $\begin{array}{c}\text { Rata- } \\
\text { rata }\end{array}$ & $\begin{array}{c}\text { Standar } \\
\text { deviasi }\end{array}$ \\
\hline 1 & $\begin{array}{l}\text { Efektivitas Penerapan Sistem } \\
\text { Informasi Akuntansi }\left(\mathrm{X}_{1}\right)\end{array}$ & 5 & 13,00 & 25,00 & 20,4691 & 2,94994 \\
& $\begin{array}{l}\text { Pemanfaatan Teknologi } \\
2\end{array}$ & & & & & \\
3 & Informasi $\left(\mathrm{X}_{2}\right)$ & 6 & 14,00 & 29,00 & 23,5185 & 4,24886 \\
4 & Motivasi Kerja $\left(\mathrm{X}_{3}\right)$ & 5 & 13,00 & 25,00 & 20,4321 & 2,87201 \\
\hline Sumber: & Kata diolah, 2019 & 5 & 12,00 & 25,00 & 20,7654 & 3,34018 \\
\hline
\end{tabular}

Berdasarkan hasil statistik deskriptif diperoleh nilai minimum efektivitas penerapan sistem informasi akuntansi sebesar 13,00 dan nilai maksimum yaitu sebesar 25,00. Rata-rata untuk variabel efektivitas penerapan sistem informasi akuntansi sebesar 20,4691, sedangkan deviasi standarnya yaitu sebesar 2,94994. Nilai deviasi standar sangat rendah dibandingkan dengan nilai rata-ratanya yang berarti bahwa sebaran data penerapan sistem informasi akuntansi menyebar secara rata. 
Berdasarkan hasil statistik deskriptif diperoleh nilai minimum pemanfaatan teknologi informasi sebesar 14,00 dan nilai maksimum sebesar 29,00 dan nilai rata-rata sebesar 23,5185 sedangkan deviasi standarnya yaitu sebesar 4,24886.Nilai deviasi standar sangat rendah dibandingkan dengan nilai rataratanya yang berarti bahwa sebaran data pemanfaatan teknologi informasi menyebar secara rata.

Berdasarkan hasil statistik deskriptif diperoleh nilai minimum motivasi kerja sebesar 13,00 dan nilai maksimum sebesar 25,00. Nilai rata-rata sebesar 20,4321, sedangkan deviasi standarnya yaitu sebesar 2,87201.Nilai deviasi standar sangat rendah dibandingkan dengan nilai rata-ratanya yang berarti bahwa sebaran data motivasi kerja menyebar secara rata.

Berdasarkan hasil statistik deskriptif diperoleh nilai minimum kinerja individu sebesar 12,00 dan nilai maksimum sebesar 25,00. Nilai rata-rata sebesar 20,7654 sedangkan deviasi standarnya yaitu sebesar 3,34018. Nilai deviasi standar sangat rendah dibandingkan dengan nilai rata-ratanya yang berarti bahwa sebaran data kinerja individu menyebar secara rata.

Tabel 9.

Hasil Uji Normalitas

\begin{tabular}{lc}
\hline \multicolumn{1}{c}{ Kolmogorov-Smirnov } & Unstandardized Residual \\
\hline $\mathrm{N}$ & 81 \\
Asymp.Sig.(2-Tailed) & 0,231 \\
\hline Sumber:Data diolah, 2019 &
\end{tabular}

Berdasarkan hasil uji normalitas, didapatkan hasil bahwa data dalam peneitian ini berdistribusi normal. 
Tabel 10.

Hasil Uji Multikolinearitas

\begin{tabular}{|c|c|c|c|c|}
\hline No & Variabel & Tolerance & VIF & Keterangan \\
\hline 1 & $\begin{array}{c}\text { Efektivitas Penerapan } \\
\text { Sistem Informasi } \\
\text { Akuntansi (X1) }\end{array}$ & 0,441 & 2,265 & $\begin{array}{c}\text { Bebas } \\
\text { Multikolonieritas }\end{array}$ \\
\hline 2 & $\begin{array}{c}\text { Pemanfaatan } \\
\text { Teknologi Informasi } \\
\text { (X2) }\end{array}$ & 0,543 & 1,840 & $\begin{array}{c}\text { Bebas } \\
\text { Multikolonieritas }\end{array}$ \\
\hline 3 & Motivasi Kerja (X3) & 0,370 & 2,706 & $\begin{array}{c}\text { Bebas } \\
\text { Multikolonieritas }\end{array}$ \\
\hline
\end{tabular}

Nilai tolerance pada masing-masing variabel independen lebih besar dari 0,10 dan nilai VIF lebih kecil dari 10 . Hal ini berarti model regresi bebas dari masalah multikolinearitas.

Tabel 11.

Hasil Uji Heteroskedastisitas

\begin{tabular}{ccc}
\hline Variabel & Sig. & Keterangan \\
\hline Efektivitas Penerapan & 0,809 & Bebas Heteroskedastisitas \\
$\quad$ Sistem Informasi & & \\
$\quad$ Akuntansi (X1) & 0,909 & Bebas Heteroskedastisitas \\
$\begin{array}{c}\text { Pemanfaatan Teknologi } \\
\text { Informasi (X2) }\end{array}$ & & \\
Motivasi Kerja (X3) & 0,193 & Bebas Heteroskedastisitas \\
\hline
\end{tabular}

Sumber:Data Diolah, 2019

Pada tabel diatas menunjukan nilai signifikasi dari masing-masing variabel adalah diatas 0,05 . Hal ini menujukan bahwa seluruh variabel tersebut bebas dari Heteroskedastisitas. 
ISSN: 2302-8556

E-Jurnal Akuntansi

Vol.28.2.Agustus (2019): 1263-1294

Tabel 12.

Hasil Analisis Regresi Linear Berganda

\begin{tabular}{|c|c|c|c|c|c|}
\hline \multirow{2}{*}{ Variabel } & \multicolumn{2}{|c|}{ Unstandardized Coefficients } & \multirow{2}{*}{$\begin{array}{c}\text { Standardized } \\
\text { Coefficients } \\
\text { Beta }\end{array}$} & \multirow{2}{*}{$\mathrm{T}$} & \multirow{2}{*}{ Sig. } \\
\hline & B & $\begin{array}{l}\text { Std. } \\
\text { Error }\end{array}$ & & & \\
\hline Constant & 1,012 & 1,783 & & 0,568 & 0,572 \\
\hline $\mathrm{X}_{1}$ & 0,276 & 0,119 & 0,244 & 2,318 & 0,023 \\
\hline $\mathrm{X}_{2}$ & 0,174 & 0,075 & 0,221 & 2,329 & 0,022 \\
\hline $\mathrm{X}_{3}$ & 0,490 & 0,134 & 0,421 & 3,663 & 0,000 \\
\hline Adjusted $R$ Square & 0,609 & & & & \\
\hline F Hitung & 42,492 & & & & \\
\hline Signifikansi F & $0,000^{\mathrm{a}}$ & & & & \\
\hline
\end{tabular}

Berdasarkan Tabel 12 diatas, dapat disusun persamaan regresi sebagai berikut:

$$
\mathrm{Y}=1,012+0,276 \mathrm{X}_{1}+0,174 \mathrm{X}_{2}+0,490 \mathrm{X}_{3}+\mathrm{e}
$$

Hasil dari persamaan regresi linear berganda pada tabel diatas menunjukan besar dan arah pengaruh masing-masing variabel independen dan variabel dependen. Koefisien regresi yang memiliki nilai positif maka memiliki pengaruh yang searah.

Nilai pada koefisien regresi dari efektivitas penerapan sistem informasi akuntansi sebesar 0,276. Angka tersebut menujukan bahwa efektivitas penerapan sistem informasi akuntansi (X1) berpengatuh positif pada kinerja individu (Y). Hal ini menyatakan apabila ada peningkatan pada efektivitas penerapan sistem informasi akuntansi (X1) akan meningkatkan kinerja individu (Y).

Nilai koefisien regresi dari pemanfaatan teknologi informasi yaitu sebesar 0,174. Angka tersebut menujukan bahwa pemanfaatan teknologi informasi (X2) berpengatuh positif pada kinerja individu (Y). Hal ini menyatakan apabila ada 
peningkatan pada pemanfaatan teknologi informasi (X2) akan meningkatkan kinerja individu $(\mathrm{Y})$.

Nilai pada koefisien regresi dari motivasi kerja (X3) sebesar 0,490. Angka tersebut menunjukan bahwa motivasi kerja (X3) sangat berpengaruh positif pada kinerja individu (Y). Hal ini menyatakan apabila ada peningkatan pada motivasi kerja (X3) akan meningkatkan kinerja individu (Y).

Uraian di atas menunjukkan bahwa koefisien regresi dari variabel motivasi kerja yang tertinggi yaitu sebesar 0,490. Ini berarti dari ketiga variabel bebas yang digunakan, variabel motivasi kerja yang paling mempengaruhi variabel terikat yaitu kinerja individu.

Berdasarkan hasil analisis dari tabel regresi linear berganda, variabel independen perpengaruh serempak (simultan) terhadap variabel dependen. Tabel 12 menyebutkan signifikasi $\mathrm{F}$ pada tabel sebesar 0,000 lebih kecil dari 0,05. Hal ini menujukan bahwa variabel independen (efektivitas penerapan sistem informasi akuntansi, pemanfaatan teknologi informasi dan motivasi kerja) dapat memprediksi atau mejelaskan fenomena kinerja individu pada Badan Keuangan Daerah Kabupaten Tabanan, sehingga dapat disimpulkan bahwa model dalam penelitian ini dikatakan layak untuk diteliti.

Variabel efektivitas penerapan sistem informasi akuntansi $\left(\mathrm{X}_{1}\right)$ mempunyai nilai signifikasi sebesar 0,023 yang lebih kecil dari $\alpha=0,05$ maka $\mathrm{H}_{1}$ diterima. Hal ini menujukan bahwa secara signifikan efektivitas penerapan sistem informasi akuntansi $\left(\mathrm{X}_{1}\right)$ berpengaruh positif terhadap kinerja individu (Y). 
Variabel pemanfaatan teknologi informasi $\left(\mathrm{X}_{2}\right)$ memiliki nilai signifikasi sebesar 0,022 yang lebih kecil dari $\alpha=0,05$ maka $\mathrm{H}_{2}$ diterima. Hal ini menujukan bahwa secara signifikan pemanfaatan teknologi informasi $\left(\mathrm{X}_{2}\right)$ perpengaruh positif terhadap kinerja individu (Y).

Variabel motivasi kerja $\left(\mathrm{X}_{3}\right)$ memiliki nilai signifikasi sebesar 0,000 yang lebih kedcil dari $\alpha=0,05$ maka $\mathrm{H}_{3}$ diterima. Hal ini menujukan bahwa secara signifikan variabel motivasi kerja $\left(\mathrm{X}_{3}\right)$ perpengaruh positif terhadap kinerja individu (Y).

Berdasarkan Tabel 12 data diperoleh pada nilai Adjusted $R$ Square sebesar 0,609. Hal ini menujukan bahwa sebesar 0,609 atau 60,9\% variasi kinerja individu (Y) dipengaruhi oleh variabel efektivitas penerapan sistem informasi akuntansi $\left(\mathrm{X}_{1}\right)$, pemanfaatan teknologi informasi $\left(\mathrm{X}_{2}\right)$ dan motivasi kerja $\left(\mathrm{X}_{3}\right)$, sisanya $39,1 \%$ dipengaruhi oleh variabel lain yang tidak masuk dalam model.

Hipotesis satu menyatakan bahwa pengaruh efektivitas penerapan sistem informasi akuntansi berpengaruh positif terhadap kinerja individu. Berdasarkan hasil pengujian dengan analisis regresi linear berganda, diperoleh nilai signifikansi sebesar 0,023 dengan nilai koefisien regresi sebesar 0.276. Nilai signifikansi $0,023<0,05$ menunjukan bahwa efektivitas penerapan sistem informasi akuntansi berpengaruh pada kinerja individu. Nilai koefisien regresi sebesar 0.276 mempunyai arti terdapat hubungan positif antara efektivitas penerapan sistem informasi akuntansi pada kinerja individu. Hal tersebut berarti semakin efektif sebuah sistem informasi akuntansi yang dimiliki Badan Keuangan Daerah Kabupaten Tabanan maka akan meningkatkan kinerja individu dalam 
Ni Luh Gede Dewi Sapitri dan I Dewa Nyoman Wiratmaja. Pengaruh ...

membuat sebuah laporan keuangan dengan sistem informasi akuntansi pemerintahan yaitu SIPKD (Sistem Informasi Pengelolaan Keuangan Daerah).

Kompetensi atau keahlian yang dimiliki karyawan harus mampu menguasi alur kerja SIPKD dalam proses melakukan perencanaan dan penganggaran, pelaksanaan dan penatausahaan dan tanggung jawab yang telah dirancang di aplikasi SIPKD. Dengan adanya kompetensi, karyawan memiliki pengetahuan yang cukup dalam memanfaatkan aplikasi SIPKD untuk membuat sebuah laporan keuangan yang sesuai dengan asas akuntansi. Keberadaan kompetensi dalam penelitian ini bisa dilihat secara langsung pada Tabel 5 (karakteristik responden). Dalam tabel tersebut secara jelas terlihat bahwa sebagian besar responden memiliki waktu yang cukup lama bekerja di Badan Keuangan Daerah Kabupaten Tabanan sehingga karyawan di Badan Keuangan Daerah Kabupaten Tabanan sudah ahli dalam menggunakan aplikasi SIPKD.

Hasil penelitian ini sejalan dengan penelitian yang dilakukan oleh (Suratini et al., 2015), (Astuti \& Dharmadiaksa, 2014)dan (Utari, 2012) yang menyatakan bahwa efektivitas sistem informasi akuntansi perpengaruh positif terhadap kinerja individual. (Eb et al., 2013)menyatakan bahwa efektivitas penggunaan berpengaruh positif terhadap kinerja individual penggunaan Sistem informasi akuntansi . Sistem informasi akuntansi dapat membantu karyawan secara efektif dan efisien dalam mengubah data menjadi informasi keuangan. Sistem informasi akuntansi yang efektiv di instansi pemerintah dapat membantu karyawan dalam memproses data secara sistematis, cepat dan akurat sehingga laporan keuangan dapat disajikan secara tepat waktu. 
Penelitian ini memberikan tambahan bukti empiris dari teori technology to performance chain (TPC). Teori TPC atau Technology to Performance Chain yaitu melakukan evaluasi pada pemakai dan kemudian menggunakannya untuk melihat keberhasilan dari teknologi sistem informasi yang digunakan oleh perusahaan. Dengan adanya model tersebut, dapat dilihat secara jelas hubungan dari kemampuan pemakai dan tugas pemakai dengan teknologi yang digunakan apakah sudah sesuai atau belum.Ketika pemakai telah memiliki pengetahuan yang cukup serta teknologi informasi yang disediakan perusahaan sesuai dengan kebutuhan pemakai dalam menyelesaikan tugasnya, maka pemakai akan memanfaatkan teknologi informasi tersebut. Temuan penelitian ini yang menujukan bahwa efektivitas penerapan sistem informasi akuntansi membuktikan bahwa pemanfaatan teknologi informasi merupakan prediktor dari kinerja.

Efektivitas penerapan sistem informasi akuntansi berpengaruh postif pada kinerja individu, ini berarti bahwa dengan adanya penerapan sistem informasi akuntansi maka kinerja akan meningkat dan dapat sebagai sumbangan pemikiran bahwa dengan adanya sistem informasi akuntansi maka kinerja individu di Bakeuda berjalan secara efektif. Pemahaman bahwa efektivitas penerapan sistem informasi akuntansi berpengaruh positif pada kinerja individu dapat dijadikan sealah satu acuan oleh Bakeuda dalam mempertahankan dan memperkuatkan kinerja individu. Perubahan kelembagaan Bakeuda yang sebelumnyan menjadi dua SKPD. Menangani urusan pelaporan keuangan di kelembagaan baru diperluas ke urusan pendapatan, menimbulkan tantangan pada upaya mempertahankan kinerja individu dan beban kerja individu yang meningkat. Berdasarkan hasil 
Ni Luh Gede Dewi Sapitri dan I Dewa Nyoman Wiratmaja. Pengaruh ...

penelitian ini dapat ditingkatkan dengan meningkatkan efektivitas penerapan sistem informasi akuntansi.

Hipotesis dua menyatakan bahwa pemanfaatan teknologi informasi berpengaruh positif terhadap kinerja individu. Berdasarkan hasil pengujian dengan analisis regresi linear berganda, diperoleh nilai signifikansi sebesar 0,022 dengan nilai koefisien regresi sebesar 0,174 . Nilai signifikansi $0,022<0,05$ menunjukan bahwa pemanfaatan teknologi informasi berpengaruh pada kinerja individu. Nilai koefisien regresi sebesar 0,174 mempunyai arti terdapat hubungan positif antara pemanfaatan teknologi informasi pada kinerja individu.

Kompetensi atau keahlian yang dimiliki karyawan harus mampu menguasi teknologi informasi sebagai sarana pendukung kinerja karyawan. Dengan adanya kompetensi, karyawan memiliki pengetahuan yang cukup dalam memanfaatkan teknologi informasi sebagai alat bantu untuk mengakses data dan menyimpan data. Keberadaan kompetensi dalam penelitian ini bisa dilihat secara langsung pada Tabel 5 (karakteristik responden). Dalam tabel tersebut secara jelas terlihat bahwa sebagian besar responden memiliki waktu yang cukup lama bekerja dan memiliki jenjang pendidikan dari S1 sampai dengan S2, hal tersebut menujukan bahwa karyawan di Badan Keuangan Daerah Kabupaten Tabanan sudah memiliki potensi dalam memanfaatkan teknologi informasi sebagai penunjang kinerja individu.

Penelitian ini sejalan dengan peneltian yang dilakukan oleh (Thompson et al., 1991), (Sugiantara \& Putra, 2017), (Utari, 2012) dan (Arsiningsih et al., 2015) yang menyatakan pemanfaatan teknologi informasi berpengaruh positif terhadap 
kinerja individu.Pemanfaatan teknologi informasi merupakan salah satu kebutuhan karyawan dalam menyelesaikan pekerjaan. Semakin lengkap fasilitas yang disediakan untuk instansi pemerintahan, maka semakin mempermudah para penggunanya untuk pemproses transaksi yang diperlukan dalam menunjang kinerja individu.

Penelitian ini memberikan tambahan bukti empiris dari Teori TPC atau Technology to Performance Chain yaitu melakukan evaluasi pada pemakai dan kemudian menggunakannya untuk melihat keberhasilan dari teknologi sistem informasi yang digunakan oleh perusahaan. Dengan adanya model tersebut, dapat dilihat secara jelas hubungan dari kemampuan pemakai dan tugas pemakai dengan teknologi yang digunakan apakah sudah sesuai atau belum.Ketika pemakai telah memiliki pengetahuan yang cukup serta teknologi informasi yang disediakan perusahaan sesuai dengan kebutuhan pemakai dalam menyelesaikan tugasnya, maka pemakai akan memanfaatkan teknologi informasi tersebut.

Hasil penelitian ini menyatakan bahwa pemanfaatan teknologi informasi berpengaruh positif pada kinerja individi. Bakeuda Kabupaten Tabanan diharapkan selalu meningkatkan cakupan dari aktivitas fitur teknologi informasi yang tersedia melalui pengambangan sistem. Selain upaya pengembangan fitur melalui pengembangan teknologi informasi, Bakeuda juga harus mampu mendorong karyawan untuk menggunakan dan memanfaatkan sistem yang ada. Dalam perspektif TPC secanggih apapun teknologi informasi dan sistem informasi akuntansi yang diimplementasikan maka kondisi tersebut tidak akan meningkatkan kinerja individu apabila tidak digunakan atau dimanfaatkan. 
Hipotesis tiga dalam penelitian ini menyatakan bahwa motivasi kerja berpengaruh positif terhadap kinerja individu. Berdasarkan hasil pengujian dengan analisis regresi linear berganda, diperoleh nilai signifikansi sebesar 0,000 dengan nilai koefisien regresi sebesar 0,490 . Nilai signifikansi $0,000<0,05$ menunjukan bahwa motivasi kerja sangat berpengaruh pada kinerja individu. Nilai koefisien regresi sebesar 0,490 mempunyai arti terdapat hubungan positif antara pemanfaatan teknologi informasi pada kinerja individu.

Penelitian ini sejalan dengan penelitian yang dilakukan oleh (Shahzadi, Javed, Pirzada, Nasreen, \& Khanam, 2014) dan(Cahyono, 2005) yang menyatakan bahwa motivasi kerja berpengaruh positif terhadap kinerja karyawan. Kinerja individu akan meningkat apabila ia mendapatkan dorongan dari dalam diri maupun dari orang lain.

Karyawan yang memiliki motivasi kerja yang tinggi maka akan mengarahkan potensi dirinya dalam mencapai tujuan instansi pemerintah dan didukung dari teori kebutuhan Maslow bahwa motivasi akan timbul apabila kebutuhan karyawan terpenuhi dari segi segi kebutuhan fisikologis, rasa aman, sosial, harga diri, dan kebutuhan aktualisasi diri dan didukung dari teori eksistence, relatedness and growth (ERG) yang menyataka bahwa karyawan akan termotivasi dalam bekerja apabila kebutuhan keberada, hubungan dan berkembang dapat terpenuhi, karena manusia adalah mahluk sosial yang selalu ketergantungan antara yang satu dengan yang lainya.

Implikasi dari penelitian ini, diharapkan Bakeuda selalu memotivasi karyawnya untuk bekerja dengan membuat lingkungan kerja nyaman, tempat 
kerja yang nyaman dan memberikan penghargaan untuk karyawan yang memiliki kinerja yang cukup bagus, sehingga motivasi karyawan di Bakeuda akan semakin meningkat.

Penelitian ini menghasilkan simpulan bahwa efektivitas penerapan sistem informasi akuntansi, pemanfaatan teknologi informasi berpengaruh positif terhadap kinerja individu di Badan Keuangan Daerah Kabupaten Tabanan. Dengan penelitian ini memberikan bukti empiris penerapan teori technology to performance chain (TPC) yang menyatakan bahwa suatu teknologi mempunyai dampak positif pada kinerja individual dan teknologi yang digunakan harus sesuai dengan teknologi - teknologi yang mendukung kinerja individu dalam suatu instansi/organisasi.

Sesuai dengan teori hirarki Maslow yang menyatakan bahwa seseorang akan termotivasi apabila kebutuhan seseorang tersebut terpenuhi secara fisiologis, keamanan, dicintai dan mencintai, harga diri dan kebutuhan aktualisasi diri. Motivasi kerja juga didukung dari teori ERG (Eksistence, Relatedness dan Growht" dimana motivasi kerja akan timbul apabila mendapatkan dorongan dari orang lain. Dalam suatu instansi pemerintah seorang pemimpin akan sukses memotivasi pegawainya apabila seorang pemimpin dapat memenuhi kebutuhan pegawainya dari segi kebutuhan keberadaan (eksistance), kebutuhan berhubungan (relatedness), dan kebutuhan untuk berkembang (growht). 


\section{SIMPULAN}

Penelitian ini bertujuan untuk menguji pengaruh efektivitas penerapan sistem informasi akuntansi, pemanfaatan teknologi dan motivasi kerja pada kinerja individu. Berdasarkan hasil pengujian hipotesis dapat disimpulkan bahwa, $\mathrm{X}_{1}, \mathrm{X}_{2}$ maupun $\mathrm{X}_{3}$ berpengaruh positif terhadap $\mathrm{Y}$.

Berdasarkan simpulan diatas, saran-saran yang dapat disimpulkan kepada peneliti selanjutnya yaitu:Bagi Instansi Bakeuda Tabanan. Jawaban responden tidak setuju terjadi pada butiran pernyataan terdapat kepala bagian atau atasan yang membantu dan mendorong baik dalam memperkenalkan maupun dalam pemanfaatan teknologi informasi. Kondisi ini menunjukan bahwa kurangnya dorongan dari atasan pada karyawan dalam memanfaatkan teknologi masih relatif rendah, dimana kontribusi atasan dalam memberikan pelatihan berkala mengenai penggunaan teknologi informasi belum optimal. Hal ini didukung dari hasil uji analisis regresi linear berganda yang menyatakan nilai koefisien regresi sebesar 0,174 dan nilai signifikansi pemanfaatan teknologi $0,022<0,05$ yang menunjukan pemanfaatan teknologi memiliki hubungan positif pada kinerja individu. Didukung dari hasil penelitian ini, diharapkan kepala bagian atau atasan dapat memberikan pelatihan dan cara memanfatakan sebuah teknologi informasi khususnya dalam menggunakan sistem informasi yang ada dan para pemakai sistem informasi dapat bekerja dengan lebih baik saat menggunakan sistem yang telah diperbaharui sesuai dengan kebutuhan instansi.

Bagi Penelitian Selanjutnya.Nilai adjusted $\mathrm{R}^{2}$ pada penelitian ini yaitu sebesar 0,609. Hal ini berarti variasi variabel kinerja individu dapat dijelaskan 
oleh variabel efektivitas penerapan sistem informasi akuntansi, pemanfaatan teknologi informasi dan motivasi kerjasebesar 60,9 \%, sedangkan sisanya sebesar $39,1 \%$ dipengaruhi oleh faktor-faktor lain yang tidak dimasukkan dalam model penelitian ini. Oleh karena itu, peneliti selanjutnya dapat menambahkan beberapa variabel bebas yang diduga mampu mempengaruhi kinerja individu. Peneliti selanjutnya juga dapat memperluas ruang lingkup penelitiannya, dengan tidak membatasi daerah pengambilan sampel hanya dengan satu daerah saja, sehingga dapat mewakili populasi yang lebih luas.

\section{REFERENSI}

Ali, A., Abrar, M., \& Haider, J. (2012). Impact of Motivation on the working performance of employees-A case study of Pakistan. Global Advanced Research Journal of Management and Business Studies, 1(4), 126-133. Retrieved from http://garj.org/garjmbs/index.htm

Alsarayreh, M., Jawabreh, O., Jaradat, M. M. F., \& ALamro, S. A. (2011). Technological impacts on effectiveness of accounting information systems (AIS) applied by Aqaba tourist hotels. European Journal of Scientific Research (Vol. Vol.59).

Antasari, K. C. (2015). Pengaruh Efektivitas Sistem Informasi Akuntansi Dan Penggunaan Teknologi Informasi Pada Kinerja Individual Dengan Kepuasan Kerja Sebagai Variabel Pemoderasi. Fakultas Ekonomi Dan Bisnis Universitas Udayana, Bali, Indonesia, 102, 2302-8556.

Arsiningsih, N. L. P. F., Diatmika, P. G., \& Darmawan, N. A. S. (2015). Pengaruh Penggunaan Teknologi Informasi, Efektivitas Sistem Informasi Akuntansi, Kepercayaan Atas Sistem Informasi Akuntansi, Sistem Pengendalian Intern Terhadap Kinerja Karyawan Pada Bank Perkreditan Rakyat Di Kabupaten Buleleng Dan Bangli. S1 Akuntansi Universitas Pendidikan Ganesha Jurusan Akuntansi Program S1, 3(1).

Astuti, N. M. M. P., \& Dharmadiaksa, I. B. (2014). Pengaruh Efektivitas Penerapan Sistem Informasi. E- Jurnal Akuntansi Universitas Udayana, 2, 373-384. 
Cahyono, S. (2005). Pengaruh Budaya Organisasi, Kepemimpinan Dan Motivasi Kerja Terhadap Kinerja Sumberdaya Manusia Di Sekretariat DPRD Propinsi Jawa Tengah. Jurnal Riset Bisnis Indonesia, 1(1), 13-30.

Darmini, A. A. S. R., \& Putra, I. N. W. A. (2007). Pemanfaatan Teknologi Informasi Dan Pengaruhnya Pada Kinerja Individual Pada Bank Perkreditan Rakyat Di Kabupaten Tabanan, 1-15.

Dewi, I. G. A., \& Puspita., L. (2014). Pengaruh Gaya Kepemimpinan Transformasional, Motivasi Kerja, dan Independensi Auditor Pada Kinerja Auditor Kantor Akuntan Publik Di Provinsi Bali. E-Jurnal Akuntansi Universitas Udayana.

Eb, A., Pretorious, P., O.J, A., \& Zuva, T. (2013). The Role Of Accounting Information Systems in Accounting Firm. International Journal of Advanced Computer Research, 1(2), 21-31.

Fahmiswari, W. (2013). Pengaruh kinerja individu karyawan terhadap efektivitas penggunaan sistem informasi akuntansi. E-Jurnal Akuntansi Universitas Udayana.

Hafeez-baig, A., \& Gururajan, R. (2011). Preliminary Study to Investigation the Determinants that Effect IS / IT Outsourcing. International Journal, 1(2).

Husein, M. F. (2008). FAKHRI 2008 komitmen org, ethics behaviour trhdp job satisfaction (indo), (1), 31-55.

Jurnali, T., \& Supomo, B. (2002). Pengaruh Faktor Kesesuaian Tugas-Teknologi Pemanfaatan TI terhadap Kinerja Akuntan Publlik. Jurnal Riset Akuntansi Indonesia, 5(2), 214-228.

Kasandra, N. M. A. A., \& Juliarsa, G. (2016). Pengaruh kualitas penerapan sia, pemanfaatan dan kepercayaan teknologi informasi pada kinerja karyawan. Jurnal Akuntansi Universitas Udayana, 14(1), 539-547.

Kristiani, W. (2012). Analisis Pengaruh Efektivitas Teknologi Sistem Informasi Akuntansi Terhadap Kinerja Individual. Jurnal Akunansi Fakultas Ekonomi Universitas Gunadarma.

Mahardhika, R., Hamid, D., \& Ruhana, I. (2018). Pengaruh Motivasi Kerja Terhadap Kinerja Karyawan (Survei Karyawan Pada PT. Axa Financial Indonesia Sales Office Malang). Management Analysis Journal, 2(1), 26-40.

Mangkunegara, A. A., \& Prabu, A. (2006). Evaluasi Kinerja SDM. Bandung: PT. Refika Aditama. 
Mathis, R. L., \& Jackson, J. H. (2006). Manajemen Sumberdaya Manusia. Jakarta: Salemba Empat.

Runtuwene, F. (2015). Pengaruh Motivasi Kerja Terhadap Kinerja Pegawai di Badan Kepegawaian Daerah Kabupaten Minahasa Selatan. Jurnal Eksekutif. Universitas Sam Ratulangi., 1(7).

Sajady, H., Dastgir, M., \& Hashem Nejad, H. (2008). Evaluation of the effectiveness of accounting information systems. International Journal of Information Science and Management, 6(2), 49-59.

Shahzadi, I., Javed, A., Pirzada, S., Nasreen, S., \& Khanam, F. (2014). Impact of Motivation on Employee Performance. European Jurnal of Business and Management, $6(23)$, 159-166. https://doi.org/10.24924/ijabm/2016.04/v4.iss1/76.85

Simanjuntak, Y. . (2012). Gambaran Pengetahuan, Sikap, dan Tindakan Pekerja pada bagian Produksi mengenai Penerapan Sistem Manajemen Keselamatan dan Kesehatan Kerja (SMK3) di PT. Toba Pulp Lestari Porsea Tahun 2012. Skripsi. Fakultas Kesehatan Msyarakat Universitas Sumatera Utara.

Soudani, S. N. (2012). The Usefulness of an Accounting Information System for Effective Organizational Performance. International Journal of Economics and Finance, 4(5), 136-145. https://doi.org/10.5539/ijef.v4n5p136

Sugiantara, P. P. O., \& Putra, I. M. P. D. (2017). Analisis Faktor-Faktor Yang Mempengaruhi Kinerja Karyawan Di DISPENDA Kota Denpasar. E-Jurnal Akuntansi Universitas Udayana, 20(3), 2509-2538.

Sugiyono. (2017). Metodologi Penelitian Kuantitatif, Kualitatif, dan R\&D. Bandung: CV Alfabeta.

Suratini, N. P. E. S., Sinarwati, N. K., \& Atmadja, A. W. T. (2015). Pengaruh Efe. E-Journal S1 Ak Universitas Pendidikan Ganesha, 3(1).

Thompson, R., Higgins, C., \& Howell, J. (1991). Personal Computing: Toward a Conceptual Model of Utilization. MIS Quarterly, 15(1). https://doi.org/10.2307/249443

Utari, P. S. (2012). Pengaruh Efektivitas Sistem Informasi Akuntansi, Kepercayaan Teknologi Informasi dan Pemanfaatan Teknologi Informasi Terhadap Kinerjs Individu Pada Koperasi Simpan Pinjam di Kecamatan Denpasar Selatan. Denpasar: Skripsi Fakultas Ekonomi Universitas Udayana. 
Ni Luh Gede Dewi Sapitri dan I Dewa Nyoman Wiratmaja. Pengaruh ...

Wahyuni, I. (2014). Faktor-faktor pemanfaatan teknologi informasi dan pengaruhnyaterhadap kinerja para pemakai enterprise resource planning (erp) di pt semen tonasa.

Widodo, J. (2015). Membangun Birokrasi Berbasis Kinerja. Malang: Banyumedia Publishing.

Wilayanti, N. W., \& Dharmadiaksa, I. B. (2016). Keterlibatan dan KemampuanTeknik Personal Pada Efektivitas Penggunaan Sistem Informasi Akuntansi. E-Jurnal Akuntansi Universitas Udayana, 15(2), 1310-1337. 